\title{
QUAL 0 ALCANCE DA HUMANIZAÇÃO DO DIREITO CIVIL NO ÂMBITO DAS RELAÇÕES FAMILIARES? BREVE ANÁLISE DE RELACIONAMENTOS AFETIVOS NÃO TRADICIONAIS, SOB AS PERSPECTIVAS DA LIBERDADE E DA CIDADANIA
}

Robson Antão de Medeiros

Professor do Centro de Ciências Jurídicas da Universidade Federal da Paraíba (CCJ/UFPB). Vice-diretor do Centro de Ciências Jurídicas da Universidade Federal da Paraíba (CCJ/UFPB). Pós-doutor em Direito pela Faculdade de Direito de Universidade de Coimbra/Portugal. Email: robson.antao@gmail.com

DuIna PoRTO

Professora do Centro de Ciências Jurídicas da Universidade Federal da Paraíba (CCJ/UFPB). Doutoranda em Direitos Humanos e Desenvolvimento pela Universidade Federal da Paraíba (UFPB) e pesquisadora na Université de Lausanne (UNIL/ $\mathrm{CH}$ ). Mestra em Ciências Jurídicas, área de concentração em Direito Econômico, pela Universidade Federal da Paraíba (UFPB). Especialista em Direito Processual Civil pelo Centro Universitário de João Pessoa (UNIPÊ). Bacharela em Direito pela Universidade Federal de Pernambuco (UFPE). Email: duinaporto@hotmail.com

\section{Resumo}

O artigo trata da humanização do Direito Civil no âmbito das relaçóes familiares no intuito de perscrutar seu alcance quanto aos relacionamentos afetivos não tradicionais, quais sejam, aqueles que não se formam a partir das regras solenes do matrimônio descrito na lei civil: famílias parentais, monoparentais, pluriparentais, unióes estáveis hetero e homoafetiva e, notadamente, relacionamentos poliamorosos. Para tanto, a abordagem inclui a apreciação de questóes relacionadas às transformaçóes da família e do direito que a respalda ao longo do tempo, com foco na repersonalização e na constitucionalização do Direito de Família e nos princípios daí decorrentes: dignidade humana, solidariedade, convivência familiar, igualdade, liberdade e afetividade. A análise da temática é feita sob as perspectivas do exercício da liberdade e da cidadania, suscitando a reflexão acerca do equilíbrio que deve existir entre a autonomia privada e a ordem pública para a guarida de direitos fundamentais em uma sociedade plural e democrática.

\section{Palavras-chave}

Direito de Família; Humanização; Liberdade; Cidadania. 


\section{Abstract}

This paper discusses the humanization of civil law in the context of family relationships, and it aims to examine how it influences non-traditional relationships, such as those which don't follow the rules of solemn marriage described in the civil law: parental families, single-parent and pluriparental families or hetero and homo-affective common-law marriages and especially polyamorous relationships. Therefore, the approach embraces issues related to family transformation and the legal rights that support family over time, focusing on the humanization and constitutionalization of family law and its principles: human dignity, solidarity, family life, equality, freedom and affection. The analysis is based on the perspectives of freedom and citizenship, raising questions about the balance that must exist concerning private autonomy and public order to assure fundamental rights in a pluralistic and democratic society.

\section{Key words}

Family Law; Humanization; Freedom; Citizenship.

\section{Introdução}

O Direito Civil - em especial o Direito de Família - vem passando por profundas mudanças ao longo do tempo, uma vez que a evolução dos costumes e dos padróes comportamentais na sociedade afetou (e continua afetando) diretamente as relaçóes familiares e, portanto, sua regulamentação jurídica. A inserção da pessoa no centro protetor do direito, denominada repersonalização ou humanização, fortalece cada vez mais o debate acerca das confluências e das dissonâncias entre esse ramo jurídico privado e os Direitos Humanos. A apreciaçáo do tema no presente artigo dar-se-á notadamente no que concerne às relaçôes afetivas não tradicionais e a configuração desses relacionamentos enquanto entidades familiares no âmbito do direito brasileiro.

Diante desse mister, no primeiro tópico serão feitas consideraçóes sobre a humanização das relaçóes familiares, a partir de um breve e necessário traçado sobre a origem e a importância da família, tendo como parâmetros o pensamento de Rousseau e de Engels sobre o assunto. A humanização das relaçóes familiares será analisada através da compreensão dos significados da codificação e da constitucionalização para o Direito de Família, destacando-se a aplicabilidade dos princípios fundamentais da dignidade humana, da solidariedade, da convivência familiar, da igualdade e da liberdade.

No segundo tópico, a discussão girará em torno do alcance dessa humanização no tocante ao reconhecimento das estruturas familiares náo convencionais, quais sejam, aquelas que fogem do padrão tradicional da família advinda do matrimônio formal, como 
as famílias parentais, monoparentais, pluriparentais, as decorrentes das uniōes estáveis hetero ou homossexuais e - o caso mais polêmico - aquelas oriundas das relaçôes poliafetivas ou poliamorosas. O princípio da afetividade enriquece (e justifica) a apreciação da temática, e sua abordagem no texto será aliada aos postulados da liberdade e da cidadania e das tensóes entre a esfera da vida privada e a ordem pública, tudo isso em defesa do reconhecimento de uma família pluralista e democrática.

\section{Direito de Família e Humanização das Relações Familiares}

A família é uma entidade universal presente em todos os tipos de sociedade, podendo ser conceituada como uma realidade sociológica que constitui a base do Estado, a célula fundamental em que repousa a organização social. O vocábulo família abrange pessoas ligadas por vínculos sanguíneos ou não, compreendendo cônjuges, companheiros, a prole, parentes e afins. Enquanto construçâo cultural, a família configura uma estruturação psíquica na qual cada um de seus integrantes ocupa um lugar e exerce uma função simbólica, tendo como principal papel conferir suporte emocional ao indivíduo.

Considerada a instituiçáo humana mais sólida da sociedade, a família pressupóe alianças. Roudinesco (2003) destaca que há pelo menos duas abordagens sobre o fenômeno familiar: a primeira - sociológica, histórica ou psicanalítica - que privilegiaria o estudo vertical das filiaçóes e das geraçôes, insistindo nas continuidades ou nas distorçóes entre os pais e os filhos e na transmissão dos saberes e das atitudes herdadas entre as geraçôes; a segunda - mais antropológica - ocupar-se-ia sobretudo da descrição horizontal, estrutural ou comparativa das alianças, enfatizando-se que cada família provém sempre da união (e, portanto, também do estilhaçamento) de duas outras famílias.

Para além das realidades supracitadas, a família insere-se em um contexto institucional profundamente político tanto nos fatores que a condicionam como em seus desdobramentos, definindo-se em um conjunto de normas, práticas e valores que têm seu lugar, seu tempo e uma história (BIROLI, 2014), sendo merecedora da mais ampla proteçáo jurídico-estatal, a exemplo da sua tutela pela Declaração Universal dos Direitos Humanos (1948), DUDH, pela Constituição da República Federativa do Brasil (1988), CF/88, e pelo Código Civil Brasileiro (2002), CC/02.

Essa especial atenção que a família recebe do Estado justifica-se em razão de ser considerada a célula da sociedade, representando, na verdade, o primeiro agente de socialização do indivíduo. Nas palavras de Lima (1960), a família não é um fruto da sociedade; é a própria semente da sociedade. É o grupo inicial e fundamental, tendente a harmonizar as relaçóes sociais e parâmetro para todos os demais grupos sociais como o Estado, a nação, a comunidade internacional, a escola, a empresa, a Igreja, porquanto todos dependem da família, que lhes fornece o elemento sem o qual nenhum deles existiria: o ser humano. Nesse sentido: 
A família humana constitui o início e o elemento essencial da sociedade. Qualquer início tende para um fim da mesma natureza, e qualquer elemento tende para a perfeição do conjunto de que esse elemento é parte. É evidente, por isso mesmo, que a paz na sociedade deve depender da paz na família e que a ordem e a harmonia dos governantes e dos governados brotam diretamente da ordem e da harmonia que nascem da direção criativa e da resposta proporcionada no seio da família. (SANTO AGOSTINHO, 1964, Livro XIX, cap. XVI, p. 15).

A correlação entre família e sociedade, pois, é inquestionável, sendo lícito afirmar que a instituição social família precede ao próprio Estado e ao direito que a regulamenta. Sem pretender rebuscar em demasia a história sobre as origens da família, até porque isso envolveria a indagação acerca da origem e da evolução da própria da espécie humana, o que extrapolaria os desideratos deste artigo, elegem-se as consideraçóes de Rousseau (s/d) e Engels (s/d) para a reflexão sobre a temática.

Discorrendo sobre a origem da desigualdade entre os homens, em sua crítica contundente à sociedade moderna, Rousseau (s/d) argumenta que a ideia de compromisso mútuo entre os homens e das vantagens de cumpri-los desenvolveu-se a partir das dificuldades (naturais, climáticas) surgidas para o gênero humano ao longo de sua existência, dificuldades que impulsionaram o progresso e fizeram surgir no espírito humano a percepção de certas relaçóes:

À medida em que o gênero humano se estendia, as dificuldades se multiplicavam para os homens. A diferença dos terrenos, dos climas, das estações, deve tê-los forçado a incluí-la em sua maneira de viver. Anos estéreis, invernos longos e rudes, veróes escaldantes que tudo consomem exigiram deles uma nova indústria. Ao longo do mar e dos rios, inventaram a linha e o anzol e se tornaram pescadores e ictiófagos. Nas florestas, fizeram arcos e flechas e se tornaram caçadores e guerreiros. Nos países frios, cobriram-se de peles de animais por eles mortos. O trovão, um vulcão ou qualquer feliz acaso levou-os a conhecer o fogo, novo recurso contra o rigor do inverno. Aprenderam a conservar esse elemento, depois a reproduzi-lo e enfim a preparar neles as carnes que antes devoraram cruas.

Essa aplicação reiterada dos seres diversos de si mesmos e de uns para com os outros teve naturalmente de engendrar, no espírito do homem, as percepçóes de certas relaçóes. Essas relaçôes que exprimimos pelas palavras grande, pequeno, forte, fraco, depressa, devagar, medroso, ousado e outras ideias semelhantes, comparadas quando necessário e quase sem nisso pensar, produziram nele, finalmente, uma espécie de reflexão, ou melhor, uma prudência maquinal que lhe indicava as precauçóes mais necessárias à sua segurança. (ROUSSEAU, s/d, p. 58).

Esses primeiros progressos, continua Rousseau (s/d), habilitaram o homem a fazer outros mais rápidos e a aperfeiçoar uma indústria rudimentar que possibilitou a construção 
de habitações, período em que se estabeleceu a distinção das famílias e a introdução de uma espécie de propriedade de onde surgiram muitas rixas e combates. Como os mais fortes foram provavelmente os primeiros a construir alojamentos que se sentiam capazes de defender, acredita-se que os mais fracos tenham achado mais simples e seguro imitá-los ao invés de tentar desalojá-los. Nesse ponto, o autor, com sua peculiar verve romântica, faz o seguinte comentário sobre a entidade familiar:

Os primeiros desdobramentos do coração foram o efeito de uma situação nova que reunia numa habitaçáo comum os maridos e as mulheres, os pais e os filhos. O hábito de viver coletivamente fez surgir os mais doces sentimentos conhecidos dos homens, o amor conjugal e o amor paternal. Cada família se torna uma pequena sociedade tanto mais unida quanto o apego mútuo e a liberdade eram seus únicos laços. Foi entáo que se estabeleceu a primeira diferença na maneira de viver dos dois sexos (...) (ROUSSEAU, s/d, p. 60).

A partir daí, Rousseau (s/d) desenvolve seus argumentos para defender como a domesticação do gênero humano, o fortalecimento dos laços, dos deveres de civilidade e da percepçáo da necessidade de auxílio mútuo acabaram por impulsionar a desigualdade entre os homens e a introdução da ideia de propriedade. Nesse sentido, também é imperioso destacar o pensamento de Engels (s/d), que, ao tratar da origem da família, fá-lo conjuntamente com a origem da propriedade privada e do Estado, demonstrando as correlaçóes entre essas instituiçóes.

Com efeito, Engels (s/d) disserta sobre a importância da família para a formação da sociedade moderna, demonstrando como o declínio da estrutura familiar primitiva colaborou para a lapidação dessa sociedade calcada na propriedade privada, na produção, no comércio e no poder do Estado. Para o autor, a derrocada desse molde familiar - enquanto célula-mater de uma economia de subsistência comunista, organizada em grupos de interesses e propriedade comuns, regida por leis que derivavam do poder materno ou do poder paterno, em que os laços de parentesco eram vitais para a sua sobrevivência harmoniosa, num tempo em que não havia produção de excedentes e atividade comercial - foi essencial à configuração de novas modalidades da vida em sociedade ${ }^{1}$.

1 O autor narra a transição da poligamia (barbárie) para a monogamia (civilização antiga) e do direito materno para o paterno na organização familiar: a primitiva ordem de descendência familiar baseava-se no direito materno, dada a ausência de monogamia e a impossibilidade de estabelecer com segurança a paternidade, de modo que a filiação estabelecia-se com a linhagem feminina, e as mulheres, como genitoras das novas geraçóes, gozavam de elevado grau de apreço. A descoberta da primitiva gens de direito materno como fase anterior à gens de direito paterno dos povos civilizados teria, para a história primitiva, a mesma importância que teoria darwiniana para a biologia e a teoria marxista da mais-valia para a economia política. As transformaçóes da família são assim apresentadas: (i) a família consanguínea, cujos grupos conjugais se separavam por geraçóes (os avôs e avós eram, no âmbito da família, 
Pela concepção materialista, em última instância o fator determinante na história é a produção e a representação da vida imediata, que se apresentam de duas formas: de um lado, a produção dos meios de subsistência, de alimentos, de habitação e de instrumentos necessários para isso; de outro, a produção do mesmo homem, a reprodução da espécie. A ordem social em que vivem os homens de uma determinada época histórica e de um determinado país condiciona-se por esses dois tipos de produção, quais sejam, pelo grau de desenvolvimento do trabalho e pela família. A ordem social será mais fortemente dominada por laços de parentesco quanto menos desenvolvido for o trabalho, a quantidade de produtos e de riqueza dessa sociedade. E nessa configuração inicial da sociedade fundada nos laços de parentesco, à medida que a produtividade do trabalho aumenta, desenvolvem-se a propriedade privada, as trocas, as diferenças de riquezas, a possibilidade de utilização da força de trabalho alheia e, com isso tudo, a base dos antagonismos de classe (ENGELS, s/d). Assim,

(...) novos elementos sociais que, no transcorrer de geraçóes, procuram adaptar a velha organização social às novas condições, até que, por fim, a incompatibilidade entre ambas produz uma transformação completa. A velha sociedade, baseada nos laços de parentesco, é destruída em decorrência do choque entre as classes sociais recém-formadas. Em seu lugar, surge uma nova sociedade, organizada em Estado, cujas unidades inferiores já não são agrupamentos sedimentados em laços de parentesco, mas unidades territoriais, uma sociedade em que o regime familiar está totalmente submetido às relaçôes de propriedade e na qual se desenvolvem livremente as oposiçóes de classe, as lutas de classe que constituem o conteúdo de toda a história escrita até nossos dias. (ENGELS, s/d, p. 12).

A influência das relaçóes de propriedade nas relaçóes familiares ainda está presente até os dias hodiernos, mesmo diante do fenômeno da humanização do direito abordado neste ensaio. Realmente, tomando como exemplo o Direito Civil brasileiro, o Código Civil de 1916, vigente até o ano de 2002, estruturou o Direito de Família sob as influências do Direito Canônico, da legislação civilista napoleônica e até das Ordenações Portuguesas, de forma estatizada, patriarcal, patrimonialista, conservadora e individualista ${ }^{2}$, reconhecendo como família apenas aquela oriunda do casamento, em uma visão estreita

maridos e mulheres entre si, assim como os seus respectivos filhos - os pais e mães), não havendo vedação de relaçôes sexuais entre irmãos); (ii) a família punaluana, que passou a excluir as relaçôes sexuais entre irmãos; (iii) a família pré-monogâmica, que excluía o casamento por grupos outrora existente, mas ainda não tinha a solidez dos laços conjugais; (iv) e a família monogâmica, configuradora da civilização nascente, baseada no domínio do homem - a quem, todavia, era permitida a infidelidade - com a finalidade explícita de procriar filhos cuja paternidade fosse indiscutível, exigindo-se a confirmação da filiação por questốes e sucessão hereditária (Cf. Engels, s/d).

2 E não poderia ser diferente, já que refletia o contexto e as ideias da época. 
que também impedia a sua dissolução ${ }^{3}$. Dizendo de outro modo, adotou o esquema das diferenças de estatuto pessoal dos cônjuges no matrimônio, afora a distinção entre filiação legítima e ilegítima, e da divisão de funçôes entre homem e mulher na família (o homem era o "cabeça" do casal, o chefe da família, ao passo que a mulher casada não passava de um ser relativamente incapaz ${ }^{4}$ ), apenas para citar algumas peculiaridades. A sacralização da família e seu reconhecimento a partir de molduras legais discriminatórias e engessadas ratificavam a forte ingerência estatal na seara familiar e a preocupação exacerbada com a proteção do patrimônio (propriedade).

Durante muito tempo, a legislação nacional acerca da família voltou-se precipuamente para o ato mais solene do Direito Civil: o casamento e suas consequências jurídicas. Era a partir do casamento, uma das instituiçóes mais poderosas do direito privado, sacramentado em bases religiosas e legais que o tornaram peça-chave do sistema social, que se formava a chamada familia matrimonial. Tanto a Igreja como o Estado ainda o sustentam de forma cabal, na medida em que regulam as relaçóes afetivas da vida das pessoas impondo regras, interditos e proibiçóes. O casamento certamente é um dos atos mais solenes do mundo jurídico, exigindo um processo minucioso de habilitação, celebração e registro e, mesmo com a evolução histórico-legislativa ${ }^{5}$, continua permeado por normas cogentes e conservadoras.

O fenômeno das codificaçóes encampadas pelo ideário dogmático liberal aprisionou a família a padróes estáticos e formais, influenciados por dogmas religiosos e pela premissa de proteção patrimonial em detrimento dos interesses pessoais (CARVALHO, 2012) ${ }^{6}$. No período de elaboração do CC/16, a sociedade brasileira tinha seus principais pilares em bases rurais e caracterizava-se por um acentuado "primitivismo patriarcal" (GOMES, 2003, p. 18); a estrutura familiar refletida na legislação civilista fundava-se no patriarcado,

3 Afinal, a possibilidade do divórcio só surgiu em 1977, com a promulgaçáo da Lei 6.515/62. Ou seja, antes disso o vínculo matrimonial era indissolúvel, não havia a liberdade para se desvencilhar legalmente do casamento, o que consiste em uma verdadeira afronta à liberdade e à dignidade das pessoas envolvidas na relaçáo. Por outro lado, o reconhecimento jurídico e social da família como aquela apenas oriunda do matrimônio deixava à margem as famílias monoparentais e as decorrentes das uniốes informais, apenas para citar duas em rol não exaustivo, por representarem uma desestruturaçáo dessa família matrimonial.

4 A capacidade plena da mulher casada só foi assegurada na década de 60 do século passado, através da Lei 4.121/62, conhecida como o Estatuto da Mulher Casada. O reconhecimento dessa capacidade plena e a difusão dos métodos contraceptivos fomentaram uma verdadeira revoluçáo sexual e a demanda posterior pela tutela de diferentes tipos de arranjos familiares.

5 A Lei 6.515/77 (Lei do Divórcio) eliminou a indissolubilidade do casamento; a Lei 11.441/07 permitiu sua dissolução extrajudicial; e a Emenda Constitucional 66/2010, que deu nova redação ao $\$ 6^{\circ}$ do art. $226 \mathrm{da}$ CF/88, para declarar que "o casamento civil pode ser dissolvido pelo divórcio", afastou a exigência de separação judicial prévia ao divórcio direto e a necessidade de identificação de culpados pelo fim do relacionamento.

6 Carvalho (2012) destaca que a publicização do Direito Civil veio acompanhada de uma crescente intervenção estatal, sobremodo no âmbito legislativo, caracterizador do Estado Social. 
na desigualdade e na submissão. A mudança de tais parâmetros só ocorreu com a promulgação da Constituição Federal de 1988, que, pautada nos paradigmas da igualdade e da dignidade da pessoa humana, imprimiu novos rumos ao Direito de Família no intuito de humanizar as relaçóes familiares.

$\mathrm{O}$ advento do constitucionalismo representou a consagração de princípios jurídicos fundamentais no campo constitucional, condicionando sua aplicabilidade no âmbito infraconstitucional, tanto que o Código Civil de 2002 atualizou diversos aspectos essenciais no tocante ao Direito de Família, embora ainda tenha deixado a desejar. Dias (2011) salienta que, não obstante o CC/02 tenha entrado em vigor 2003, o projeto original data de 1975 e, por isso, sofreu inúmeras emendas para se adequar às diretrizes constitucionais de 1988. Apesar dos avanços, a inclusão retalhada das novas concepções do Direito de Família causou certa desordem estrutural, sendo o dirigismo estatal ainda bastante presente nas relaçóes familiares, o que, em muitas situaçóes, acaba por violar a privacidade, a liberdade e a dignidade das pessoas ${ }^{7}$.

Assim, entre retrocessos e avanços ${ }^{8}$, com a Carta de 1988 e a constitucionalização do Direito Civil, quando os sustentáculos dos institutos civilistas clássicos não apenas da família, mas também da propriedade e do contrato, passaram a ser assunto constitucional, o Direito de Família absorveu inúmeros reflexos desse processo transformativo. Tais institutos, que eram de cunho bastante patrimonializados, passaram a ser humanizados, personalizados ou repersonalizados, na medida em que a pessoa passou a ocupar um lugar privilegiado no que concerne à tutela de direitos.

Ao fixar os direitos e garantias fundamentais antes mesmo da traçar as estruturas essenciais do Estado, a CF/88 evidencia ser um instrumento voltado à concretização da democracia a serviço da sociedade, ressaltando-se que, nas Cartas anteriores, o tratamento constitucional conferido ao Estado sempre antecedia, na ordem das disposiçóes normativas constitucionais, ao tratamento conferido aos direitos individuais. Essa estrutura lógico-textual é reflexo inegável dos valores extraídos da Declaração Universal dos Direitos do Homem (OLIVEIRA, 2012).

A previsão de princípios aplicáveis ao Ius Familiae trouxe novos matizes para esse ramo jurídico, possibilitando uma maior adequação das normas à dinâmica social que estava distanciada da moldura arcaica do Código Civil de 1916. Os princípios constitucionais expressos que permeiam o Direito de Família compreendem - dentre os demais

7 Exemplos disso são o tratamento desigual entre as entidades familiares decorrentes do casamento e da uniâo estável e a ausência de normatização das unióes homoafetivas (Cf. DIAS, 2011).

8 Dias (2011) cita alguns avanços: a incorporação de orientaçóes jurisprudenciais e a supressão de dispositivos que retratavam ranços e preconceitos, como as adjetivaçóes de filiação, o regime dotal e as referências desigualitárias entre o homem e a mulher. 
que podem ser extraídos dos artigos 226, 227 e 230, como a afetividade, que será tratada mais adiante - a dignidade humana, a solidariedade, a convivência familiar, a igualdade e a liberdade.

Em breves linhas, o princípio da dignidade humana, fundamento da ordem jurídica constitucional e valor nuclear do Estado Democrático de Direito, explicitado no artigo 1º, III, da Constituição Federal, revela a expressa opção do legislador constituinte pela pessoa, representando, assim, tanto um freio à atuação estatal, na medida em que é vedado ao Estado praticar atos atentatórios à dignidade, como um suporte para sua ação positiva, já que o Estado tem o dever de promover essa dignidade mediante condutas ativas, assegurando o mínimo existencial para cada ser humano em seu território. A dignidade humana encontra na família o solo apropriado para florescer, estando o Direito das Famílias umbilicalmente ligado aos Direitos Humanos, como afirma Dias (2011).

O princípio da solidariedade familiar tem pertinência com o compartilhamento de afetos e de responsabilidades, tendo em vista que o ser humano não existe sozinho: ele coexiste. Está relacionado à fraternidade e à reciprocidade, podendo-se extrair dos deveres de assistência entre pais e filhos (CF/88, artigo 229) e de amparo aos idosos (CF/88, artigo 230), encontrando eco ainda no estabelecimento da plena comunhão de vidas no casamento e na obrigação alimentar (previstos, respectivamente, nos artigos. $1.511 \mathrm{e}$ 1.694 do Código Civil). Quanto ao princípio da convivência, o dispositivo constitucional que melhor o traduz é o artigo 227, segundo o qual a convivência familiar é prioridade absoluta da criança, do adolescente e do jovem, consistindo em um dever não apenas da família, mas também da sociedade e do Estado.

No que tange ao princípio da igualdade (e do respeito à diferença), é conclamado no caput do artigo $5^{\circ}$ da Constituição, que declara que "todos são iguais perante a lei", e no inciso I desse mesmo dispositivo, prevendo a igualdade de homens e mulheres em direitos e obrigaçóes. De forma específica para o Direito de Família, o princípio em comento revela-se na igualdade entre os cônjuges consoante o $\$ 5^{\circ}$ do artigo 226: "Os direitos e deveres referentes à sociedade conjugal são exercidos igualmente pelo homem e pela mulher”. Em respeito ao mesmo princípio, o $\$ 7^{\circ}$ desse artigo assegura a liberdade do casal sobre o planejamento familiar, repudiando qualquer coerção por parte de instituiçóes públicas ou privadas, e limitando a ingerência do Estado, cujo dever é propiciar recursos educacionais e financeiros para o exercício desse direito.

A possibilidade de existência de diversos formatos de famílias, sem hierarquia entre as mesmas (CF/88, artigo 226), e a paridade entre os filhos independentemente da origem também representam o princípio da igualdade, diretamente correlacionado ao princípio da liberdade. O $\$ 6^{\circ}$ do artigo 227 da Constituiçáo textualiza que "os filhos, havidos ou não da relação do casamento, ou por adoção, terão os mesmos direitos e qualificações, proibidas quaisquer designaçôes discriminatórias relativas à filiação”, afastando 
rótulos que marcaram geraçôes de filhos "espúrios", "ilegítimos" e "bastardos" aviltados em seus direitos.

O princípio da liberdade é correlato ao da igualdade porquanto a ausência de igualdade caracteriza dominação e sujeição, incompatíveis, pois, com a liberdade. A aplicabilidade do princípio da liberdade no Direito de Família permite às pessoas exercer sua autonomia da vontade, a partir das escolhas que concernem à sua privacidade. Ao mesmo tempo, autoriza o reconhecimento público dessas escolhas e a possibilidade de exercício dos direitos daí decorrentes.

A CF/88 e o CC/02, assim, elencam princípios e normas referentes à família, estabelecendo sua estrutura e evidenciando a proteção estatal que lhe é conferida. O capítulo VII da CF/88, intitulado "Da Família, da Criança, do Adolescente, do Jovem e do Idoso", traz no artigo 226 que "a família, base da sociedade, tem especial proteção do Estado”. Já o Livro IV do CC/02 regulamenta o "Direito de Família”, entre os artigos 1.511 a 1.783 , deixando claro que sua natureza jurídica é de caráter privado. Na verdade, não obstante o perfil privatístico, as normas atinentes às relaçôes familiares são nitidamente imperativas e de ordem pública, disciplinando e limitando uma gama de situações (o casamento é o melhor exemplo para ilustrar essa afirmação).

A humanização das relaçóes de Direito de Família perpassa necessariamente por esse caminho traçado pela constitucionalização, pela busca da melhor interpretação das diretrizes previstas na Constituição para a efetivação de direitos fundamentais ${ }^{9}$. O $\$ 5^{\circ}$ do artigo 226 da CF/88, estabelecendo a igualdade entre os cônjuges no casamento, e o artigo 227, que atribuiu aos filhos a posição de centralidade no grupo familiar, assegurando prioridade às crianças e aos adolescentes, consolidam esse papel "humanizador" e ratificam a adoção da cláusula geral de tutela da pessoa humana.

Carvalho (2012) discorre sobre o Direito Civil como elemento de aproximação entre o sistema normativo e o meio social e sobre o papel da Teoria Geral do Direito no enfrentamento dos embates quanto à aplicabilidade de preceitos à realidade fática, com o propósito de fazer prevalecer o ideal de justiça e de igualdade, enfatizando a influência de uma consciência jurídica social sobre o método interpretativo, a qual se aplicaria através dos profissionais e estudiosos da ciência jurídica.

Essa consciência jurídica social resvalar-se-ia por dois caminhos distintos de análise: primeiro, o mecanismo da política jurídica, que circunda todo o ordenamento e invade os elementos interpretativos das normas, espelhando a própria aplicação do Direito em

9 No campo do direito privado, destacam-se, dentre os direitos fundamentais, os denominados direitos personalíssimos, ou seja, aqueles referentes à pessoa natural, que existe em todos os seus predicados e em sua individualidade, com aptidão, assim, de receber os atributos da personalidade jurídica (Cf. CARVALHO, 2012). 
si; segundo, a questão da representação simbólica das normas jurídicas, que se perfazem, pragmaticamente, em meandros interpretativos próprios, utilizando-se, muitas vezes, da política jurídica como parâmetro (CARVALHO, 2012).

O raciocínio do autor continua no sentido de ratificar a existência de uma crise de paradigmas - e de interpretação - que obstaculiza a realização das normas previstas na Carta Magna, uma vez que os modelos tradicionalmente utilizados restam insuficientes para reger os padróes hodiernos de comportamento. Com efeito, essa crise é sentida com vigor no Direito de Família, ramo em que a dificuldade de adequação entre as constantes mudanças sociais e o ordenamento jurídico é uma realidade. A efetiva humanização do Direito de Família, portanto, depende da solução do confronto entre os modelos jurídicos postos e os novos dilemas surgidos no seio da sociedade, no intuito de combater resquícios liberais-individualistas presentes nas normas jurídicas de Direito Civil. Nesse aspecto:

(...) os direitos de famílias aparentavam ser imunes a qualquer forma de influência ao longo do tempo, mantendo suas raízes e seus arraigados conceitos em fundamentos pretéritos. Seus institutos vinham permanecendo válidos em regras imemoriais, adversas, até, às modificaçôes nas cartas políticas de cada Estado.

A tradição romana de nossa legislação, principalmente aquela relativa às relaçóes civilísticas, forjou modelos hermenêuticos amplamente parametrados na estrutura liberal-individualista da norma, com grande aspecto dogmático em sua forma mais comum. O caráter institucional do dogmatismo chega a ser tão presente que é possível se enquadrar situaçôes que estão de acordo com a norma, mas que contrariam diretamente o ideal de justiça. (CARVALHO, 2012, p. 20).

A ideia da humanização do Direito de Família, para além dos aspectos patrimoniais (ter) com ênfase à tutela de direitos do próprio homem enquanto ser, não pode deixar de lado a reflexão acerca da insuficiência do dogmatismo para suprir as demandas de uma sociedade democrática e pluralista, ainda mais quando se observa um crescente desejo de normatização das relaçóes afetivas que sempre estiveram à margem do direito.

Realmente, Roudinesco (2003) atenta para o fato dos homossexuais manifestarem esse desejo de normatização, a reivindicação ao casamento, à adoção e à procriação medicamente assistida, questionando o que teria ocorrido nos últimos trinta anos na sociedade ocidental para que essas pessoas - qualificadas de sodomitas, invertidas, perversas ou doentes mentais - tenham almejado não apenas a uma cidadania integral, mas à adoção de uma ordem familiar que tanto contribuiu para o seu infortúnio; como explicar esse "desejo de família", em especial porque "a homossexualidade sempre foi repelida da instituição do casamento e da filiação, a ponto de se tornar, ao longo dos séculos, o significante maior de um princípio de exclusão?” (ROUDINESCO, 2003, p. 7). 
Nesse mesmo compasso, insere-se a abordagem acerca das denominadas famílias paralelas, quais sejam, aquelas que envolvem vínculos afetivos concomitantes, a exemplo de um casamento e uma união estável ou duas ou mais unióes estáveis simultâneas, com a ciência ou não dos integrantes. Como enquadrar esses relacionamentos no âmbito jurídico face aos parâmetros delineados pela humanização do Direito de Família?

\section{Humanização das Relações Familiares, Famílias não Tradicionais, Liber- dade e Cidadania: Consonâncias e Dissonâncias}

As consideraçóes supramencionadas permitem afirmar que a família brasileira - bem como o direito que regulamenta - merece ser analisada em dois momentos: antes e depois da Constituição Federal de 1988. No momento anterior, havia um modelo de família tradicional, sacramentado apenas pelo casamento e regido por normas que impediam a sua dissolução, em inegável afronta à liberdade e à dignidade, tanto dos próprios contraentes quanto daqueles que não se enquadravam nas linhas dos textos legais. Com a $\mathrm{CF} / 88$, esse modelo tradicional passou a ser substituído pelo modelo democratizado, a chamada familia democrática.

A consagração da dignidade da pessoa humana como fundamento da República Federativa do Brasil contribuiu para essa evolução, representando uma conquista decisiva para a ordem jurídica privada na qual o Direito de Família se insere. A elevação desse princípio ao topo do ordenamento alterou substancialmente a estrutura outrora em vigor no direito nacional, influenciando sobremaneira a interpretação/aplicação dos institutos jurídicos. A constitucionalização do Direito de Família, impondo a igualdade conjugal e atribuindo a absoluta prioridade às crianças e adolescentes no grupo familiar, por exemplo, foi essencial ao processo de humanização das relaçóes familiares e à derrocada da estrutura patriarcal então vigente; o patriarcalismo, fundado na "tripla desigualdade de homens em relação a mulheres, pais em relação a filhos e de heterossexuais em relação a homossexuais" (BODIN DE MORAES, 2013, p. 589), perdeu seu respaldo com a CF/88. Além disso, o modelo adotado pelo constituinte ampliou as formas de organização familiar, possibilitando a proteção de novas estruturas familiares como a comunidade formada por qualquer dos pais e seus descendentes e a união estável entre o homem e a mulher.

A primeira hipótese acima referida está prevista no $\$ 4^{\circ}$ do artigo 226 da CF/88 e configura as denominadas famílias monoparentais, que representam uma real tendência da sociedade pós-moderna. $\mathrm{O}$ adjetivo monoparental remete à presença de somente um dos pais na titularidade do vínculo familiar, fenômeno presente na sociedade pós-moderna marcada pela inserção crescente da mulher no mercado de trabalho, o que, dentre outros fatores, trouxe a mudança de determinados parâmetros. De fato, a independência financeira das mulheres, que deixaram de necessitar do outro consorte para subsistir, consolidou 
a opção - e a aceitação social - de uma gama de mães solteiras; por outro lado, também possibilitou a inversão de papeis, já que muitos homens passaram a assumir a responsabilidade pela criação de seus filhos (uma função antes reservada sobremaneira às mulheres), seja para que as esposas fossem trabalhar fora de casa, seja após a dissolução do casamento.

Há que se falar ainda nas famílias parental e pluriparental que, mesmo não tendo sido enumeradas no texto constitucional, são reconhecidas pelas vias doutrinárias e jurisprudenciais ${ }^{10}$. A parental - ou anaparental - é formada entre parentes, como duas irmãs que passam a vida juntas; a pluriparental deriva do desfazimento de relaçóes afetivas pretéritas, também denominada de família recomposta. Nesse novo arranjo familiar, predomina a multiplicidade de vínculos: o novo casal, os filhos de cada de um, os filhos em comum (os meus, os teus e os nossos).

Já o reconhecimento das unióes informais ${ }^{11}$ ou não tradicionais como entidades familiares, sepultando a moldura civilista arcaica de 1916 que taxava como legitima apenas a família formada a partir do matrimônio, consagrou-se com o $\$ 3^{\circ}$ do artigo 226 da CF/88 ${ }^{12}$, a Lei 9.278/96 e o Código Civil de 2002. Os dois últimos trazem os requisitos para a configuração da união estável: convivência duradoura, pública e contínua entre um homem e uma mulher, com o objetivo da constituição de família ${ }^{13}$.

Antes dessa positivaçáo, as unióes informais eram taxadas de concubinárias, ou seja, aquelas uniōes de fato em que não havia a intenção de formar família. O concubinato era gênero com duas espécies: o "puro", entre pessoas desimpedidas; e o "impuro", adulterino ou incestuoso, entre pessoas com algum impedimento matrimonial ${ }^{14}$. Decerto que esses arquétipos deixavam desamparada a "concubina" e os filhos eventuais oriundos da relação ${ }^{15}$, e a proteção jurídica dessa situação veio inicialmente com o reconhecimento dessas uniōes como "sociedades de fato", figura típica do Direito Obrigacional, uma vez que não havia fundamento legal para serem enquadradas no Direito de Família ${ }^{16}$. A atribuição de efeitos jurídicos às unióes informais passou a ter prestígio inicialmente por meio da legislação

10 Cf. sítios do STJ e demais tribunais brasileiros.

11 Informais por não terem sido constituídas pelos moldes formais do casamento traçados minuciosamente no texto civil.

12 O referido dispositivo versa que "Para efeito da proteção do Estado, é reconhecida a união estável entre o homem e a mulher como entidade familiar, devendo a lei facilitar sua conversão em casamento".

13 Respectivamente nos artigos $1^{\circ}$ e $1.723, \$ 1^{\circ}$.

14 No Direito brasileiro, os impedimentos matrimoniais estão previstos nos artigos 1.521 e 1.522 do $\mathrm{CC} / 12$.

$15 \mathrm{O}$ artigo 337 do CC/16 previa como legitimos os filhos concebidos na constância do casamento.

$16 \mathrm{O}$ CC/16 ignorou as unióes de fato entre pessoas desimpedidas, cuidando, todavia, de sancionar o concubinato adulterino para resguardar o patrimônio da família formada a partir do matrimônio. Nesse sentido, vedava a doação do homem casado à sua "cúmplice" (artigo 1.177), que também não podia ser beneficiária do seguro de vida (artigo 1.474), herdeira ou legatária (artigo 1.719, III). 
previdenciária, porquanto nesse âmbito não se questionava a regularidade formal da instituiçáo familiar, importando, sobretudo, o conceito de dependência econômica.

Mais adiante, em 2011, no emblemático julgamento da Ação Direta de Inconstitucionalidade - ADI 4277, o Supremo Tribunal Federal reconheceu como estáveis as unióes homoafetivas, equiparando-as às entidades familiares. Em decorrência disso, como o $\$ 3^{\circ}$ do artigo 226 dispóe que a lei deve facilitar a conversão da união estável em casamento, desapareceu o impedimento para que pessoas do mesmo sexo casassem. Até então, a interpretação literal citado dispositivo constitucional conferia juridicidade apenas à união estável entre o homem e a mulher - denotando assim uma discriminação, face à ausência de motivos plausíveis para diferenciar a convivência homossexual da heterossexual, precipuamente em respeito à liberdade de escolha e à dignidade da pessoa humana.

O posicionamento humanista do STF nesse caso desbravou horizontes e abriu maior espaço para o debate concernente aos diversos arranjos familiares existentes, à pluralidade das famílias e a diversidade enquanto valor no ordenamento jurídico nacional. A decisão explicitou o pluralismo ${ }^{17}$ como valor sócio-político-cultural, vedando a discriminação das pessoas em razão do sexo através de uma interpretação não-reducionista que enfatiza que a Constituição Federal não emprestou ao substantivo "família" nenhum significado ortodoxo, pois a família exsurge como categoria sócio-cultural e princípio espiritual.

O reconhecimento dos arranjos familiares referidos está em consonância com o processo de humanização, de repersonalização do direito e de transformaçóes atinentes às relaçóes sociais; à estrutura familiar hermética que só poderia ser tutelada com o selo do casamento somam-se outras estruturas de convívio que possuem os requisitos que configuram uma família para além dos vínculos biológicos ou patrimoniais: laços afetivos, solidariedade, lealdade, confiança, respeito, amor. É impensável, no cenário atual, pensar a família a partir de um modelo pré-determinando ou de referências únicas e excludentes, até porque a Constituição é inclusiva.

A constitucionalização, a humanização das relaçóes familiares e a aceitação da família democrática e pluralista prosperaram em um contexto cada vez mais marcado pela "fluidez" dos tempos modernos, pela metamorfose social que avança em vários sentidos num mundo de mudanças rápidas e imprevisíveis que não se fixam no espaço nem se prendem ao tempo. A "modernidade líquida" de Bauman (2001) serve como metáfora apta a caracterizar essa "fluidez", no sentido da inconstância dos valores hodiernos, da dissoluçáo

17 Todo pensamento pluralista valoriza princípios como autonomia, descentralização, participação, localismo, diversidade e tolerância. O pluralismo propóe um modelo de sociedade articulada em grupos de poder que se situem, ao mesmo tempo, abaixo do Estado e acima dos indivíduos e, como tais, constituam uma garantia dos indivíduos contra o poder excessivo do Estado e, por outro lado, subsidiem e fortaleçam o próprio Estado contra a fragmentação individualista. (DALANEZE, 2010, p. 71). 
("derretimento") de pontos ou grupos de referência e estabilidade outrora existentes ("sólidos") que asseguravam certo direcionamento para a construção individual da vida.

As relações humanas foram (e são) diretamente afetados por esse "líquido cenário" (BAUMAN, 2004, p. 08), cujos padróes e configuraçóes não são mais "dados" ou "auto-evidentes"; ao contrário, são múltiplos e ambivalentes. Nessa conjuntura, amplia-se o campo para a análise dos relacionamentos que envolvem vínculos afetivos concomitantes, como um casamento e uma união estável ou duas ou mais uniôes estáveis simultâneas, com ou sem a ciência dos integrantes. Na primeira hipótese, a solução encontrada pelo direito brasileiro, igualmente em consonância com o processo de humanização, está no $\$ 1^{\circ}$ do artigo 1.723 do Código Civil, o qual admite a união estável paralela ao casamento, se comprovada a separação de fato entre marido e mulher. Essa circunstância traz à tona a seguinte situação: a ciência, por parte da (o) amante, de que o (a) companheiro (a) permanece casado (a) de fato e de direito retira-lhe o direito de ser reconhecida (o) como companheira (o) que mantém uma união estável, configurando o concubinato ${ }^{18}$ que é pautado - em princípio - pela clandestinidade e deslealdade do relacionamento.

Diferente é a segunda hipótese, que trata das unióes concomitantes com a ciência dos envolvidos e que configuraria um paralelismo afetivo sob o viés do poliamor. $\mathrm{O}$ poliamor ou poliamorismo é um termo referenciado pela literatura, cinema, televisão e, mais recentemente, pelo meio científico-acadêmico. Em um viés mais jurídico, pode ser definido como a união simultânea de vínculos afetivos entre pessoas que conjugam suas vidas com comprometimento e responsabilidades recíprocas, desafiando, portanto, o significado tradicional (e legal) do casamento. Os adeptos do poliamor enfatizam antes o amor do que a sexualidade - daí a preferência pela expressão "poliamorosos" - tendo como principal objetivo o compartilhamento de experiências e sentimentos, e não a concretização de muitas relações sexuais ${ }^{19}$. Embora haja certa instabilidade nas acepçóes da expressão, todas parecem convergir para pontos comuns: (i) que a prática do poliamor refere-se ao relacionamento afetivo simultâneo com mais de uma pessoa; (ii) que há a permissão dessas pessoas, de modo que os princípios norteadores de tais relaçóes seriam a honestidade e o consenso (FREIRE, 2013, p. 39).

$\mathrm{O}$ ordenamento jurídico brasileiro não reconhece essas uniōes como entidades familiares - o que estaria, pois, em dissonância com o processo de humanização do direito -embora já exista o registro da união civil entre três pessoas (duas mulheres e um homem) realizado em um cartório de Tupá, cidade do interior do estado de São Paulo. A oficialização

18 Código Civil, art. 1.727: "As relaçóes não eventuais entre o homem e a mulher, impedidos de casar, constituem concubinato".

19 Freire (2013, p. 41) explica que o poliamor nâo se confunde com outras categorias de ligaçóes não monogâmicas, como o "casamento aberto", "amor livre" e "swing”, que teriam propósitos meramente sexuais. 
dessa união poliafetiva teve o intuito de assegurar os direitos entre os três integrantes em caso de separação e morte, tendo a tabeliã responsável entendido que eles formavam uma união estável, razão pela qual firmou a escritura pública. Todavia, o Presidente da Ordem dos Advogados do Brasil, seccional Marília/SP, destacou que o documento funciona mais como uma sociedade patrimonial, não compreendendo todos os direitos de família ${ }^{20}$ (G1, BAURU E MARÍLIA, 2012).

A simultaneidade familiar no âmbito conjugal é uma realidade concreta repudiada pelo nosso Direito, tendo em vista que a família ocidental funda-se basicamente no princípio da monogamia ${ }^{21}$, segundo o qual cada pessoa deve viver uma relaçáo conjugal de cada vez, com exclusividade (TEIXEIRA e RODRIGUES, 2010, pp.117-118). Não obstante, as unióes afetivas paralelas existem no mundo real e geram consequências que repercutem do mundo jurídico, pois dessas relaçóes de convivência surgem muitas vezes filhos, obrigaçóes alimentares e previdenciárias, direitos sucessórios e patrimoniais. Negar efeitos a essas relaçóes é atentar contra a liberdade e privacidade dos partícipes que concordaram com a situação. E mais: como justificar essa ausência de reconhecimento face ao princípio da dignidade humana e à decantada repersonalização/humanização do Direito de Família?

Vale salientar que a aceitação dos diversos tipos de famílias evidencia um elemento intrínseco a cada uma delas e que alçou o patamar de princípio jurídico: o afeto. A noção moderna de família tem o afeto como seu aspecto mais representativo, pois é o envolvimento afetivo - antes, pois, de qualquer formalidade ou moldura legal - que possibilita o pleno desenvolvimento do ser humano, de sua individualidade e de sua privacidade. Ampliou-se o rol para a chamada família eudemonista, com realce para o sentido da afetividade e da busca da felicidade ${ }^{22}$. Apesar da $\mathrm{CF} / 88$ não mencionar literalmente a afetividade

20 Saliente-se que a união estável, antes de ser reconhecida como entidade familiar, era vista como sociedade de fato, conforme mencionado neste artigo. Assim, esse pode ser o primeiro passo para que os relacionamentos poliafetivos também possam ser considerados entidades familiares.

21 Embora a Europa também acredite na monogamia, sendo a bigamia considerada crime na maioria dos seus sistemas, a poligamia vem sendo introduzida no Direito de Família europeu: "[...] while the principle of monogamy has been maintained, polygamy has been introduced into family law in Europe, first, as serial polygamy, with the possibility of remarriage and second, simultaneous polygamy, with acceptance of some of the consequences of marriages entered into in the other legal systems where this form is recognized, combining remarriage with sometimes life long subsistence of some economic rights and duties of former marriages, institutionalized unmarried cohabitation giving rise to rights and duties in relation to two partners, and the possibility for a man to have children with the same legal status by more than one woman.” (ÖRÜCÜ, 2009, p. 526). Nesse sentido, já houve registro na Holanda da uniāo civil entre três pessoas (BELIEN, 2015).

22 A expressão "eudemonismo", de origem grega, liga-se ao adjetivo "feliz" e denomina a doutrina que admite ser a felicidade individual ou coletiva o fundamento da conduta humana moral. A família eudemonista surge para nominar essa nova tendência de identificar a família pelo seu envolvimento afetivo (DIAS, 2011, p. 55). 
como princípio aplicável às relaçôes de família, tal como aponta a dignidade humana (artigo $1^{\circ}$, III), a solidariedade (artigo $3^{\circ}$, III), a igualdade (artigos $5^{\circ}$, caput; 226, $\$ 5^{\circ}$ e 227 , $\$ 6^{\circ}$ ), o melhor interesse do menor e a convivência familiar (artigo 227), sua inclusão no elenco principiológico resta patente, sobretudo por especializar princípios supracitados.

A importante presença do afeto na discussão jurídica atual exsurge com a significativa mudança na percepção e na vivência das famílias; o afeto se sobressai nas relaçóes familiares em um contexto em que o exercício da liberdade vem aumentando em comparaçáo aos tempos passados. Deveras, quando a ideia de família vinculava-se estritamente aos laços indissolúveis do matrimônio e à descendência oriunda desse enlace, os motivos que uniam e mantinham tais famílias eram diversos; decerto que o afeto constava como um dos motivos, mas náo havia o poder conferido pela liberdade de estar, sair, acolher, afora a primazia exagerada conferida às questóes patrimoniais e a desigualdade entre filhos e entre homens e mulheres. Todas essas questóes, outrora, "conferiam razóes para 'estar junto’ que podiam coincidir ou não com um sentimento de inclinação emocional pelo outro" (OLIVEIRA, 2010, p. 51).

O princípio em comento, pois, passou a reluzir a humanização do Direito de Família na medida em que a juridicização do afeto revolucionou as relaçóes interpessoais, promovendo uma salutar reforma de valores e estreitando as ligaçóes (consonâncias) entre afetividade e Direitos Humanos:

Desde a incidência da teoria da afetividade, várias alteraçôes podem ser observadas sob esta perspectiva: a visão do casamento baseado no afeto entre marido e mulher justifica a separação em caso de não haver mais interesse em estar casados; a afinidade entre companheiros justifica a 'legalização' das unióes livres; a guarda compartilhada surge como instrumento apto a evitar a perda do convívio afetivo entre pais separados e os filhos; a paternidade socioafetiva remodelou a relação paterno-filial, desvinculando-a do critério sanguíneo, e as uniôes homoafetiva ganham espaço por revelarem a afetividade existente entre casais formados por pessoas do mesmo sexo.

Imprescindível mencionar que a fundamentação do afeto não pode ser dissociada da categorizaçáo dos Direitos Humanos. O estudo das geraçôes que classifica os direitos fundamentais permite uma análise no que tange à concretizaçáo do direito ao afeto, como sendo uma garantia de liberdade. (CARVALHO, 2012, pp. 177-178)

$\mathrm{O}$ afeto consubstancia-se em uma liberdade constitucional, tanto quanto a liberdade locomoção, de expressão e de religião, gerando direitos individuais (direito ao afeto) e, por conseguinte, responsabilidades daí decorrentes. O advento jurídico do afeto ocasionou uma "legítima refundação familiar, agora alicerçada na égide da igualdade material, da proibição da discriminação e na efetividade da cidadania” (CARVALHO, 2012, p. 14). 
Essa refundação familiar pautada na afetividade propicia o exercício da liberdade e da cidadania em sua plenitude; liberdade enquanto valor supremo perseguido pelo indivíduo, relacionada ao poder que o cidadão tem de exercer suas faculdades dentro dos limites legais, e cidadania enquanto qualidade da pessoa titular de direitos e obrigaçóes, categoria político-participativa e modo de pertencimento à sociedade. De outro modo, restringir o direito de formar uma família que não se enquadra nos padróes convencionais representa, a princípio, uma afronta a esses postulados, além de estar em dissonância com a repersonalização do Direito, que, repita-se, insere a pessoa no seu centro protetor. Assim, se por lado houve uma evolução no sentido da guarida das famílias monoparentais, pluriparentais, anaparentais e daquelas formadas pela uniáo estável de hetero ou de homossexuais, por outro, o não reconhecimento de arranjos afetivos como os poliamorosos consentidos estaria à margem dessa humanização e de seus corolários.

Que razôes poderiam ser elencadas para tal vedação? O princípio da monogamia? A coibição da bigamia? A proteção patrimonial? Conservadorismo? E como defender o princípio da afetividade, o exercício da liberdade e da cidadania diante desses impasses?

A temática da liberdade está intrinsecamente ligada à independência e à autonomia da vontade, podendo ser concebida como valor ou ideal almejado pelo indivíduo. Como já mencionado neste artigo, o sentido do princípio da liberdade no Direito de Família é permitir às pessoas exercer essa autonomia a partir das escolhas que concernem à sua privacidade, autorizando também o reconhecimento público dessas escolhas e a possibilidade de exercício dos direitos daí advindos, que se traduz em cidadania. Nesse sentido:

Em face do primado da liberdade, é assegurado o direito de constituir uma relação conjugal, uma união estável hetero ou homossexual. Há a liberdade de dissolver o casamento e extinguir a união estável, bem como o direito de recompor novas estruturas de convívio. A possibilidade de alteração do regime de bens na vigência do casamento (CC $1.639 \$ 2^{\circ}$ ) sinala que a liberdade, cada vez mais, vem marcando as relaçóes familiares.

No rol dos direitos da criança, do adolescente e do jovem, assegurados constitucionalmente, figura o direito à liberdade (CF 227). Assenta-se neste direito tanto a necessidade de o adotado, desde os 12 anos de idade, concordar com a adoçáo (ECA $45 \$ 2^{\circ}$ ), como a possibilidade do filho de impugnar o reconhecimento levado a efeitos enquanto era menor de idade (CC 1.614). Igualmente o ECA consagra como direito fundamental a liberdade de opinião e de expressão (ECA 16 II) e a liberdade de participar da vida familiar e comunitária sem discriminação (ECA 16 V). (DIAS, 2011, p. 64).

Por sua vez, a Declaração de Direitos do Homem e do Cidadão (1789) versa que a liberdade consiste em poder fazer tudo o que não prejudique o próximo. Ao estabelecer, em seu artigo 16, que a família é o núcleo natural e fundamental da sociedade e tem 
direito à proteção desta e do Estado, a DUDH evidencia a preocupação que deve estar afeta ao Estado no sentido de tutelar essa instituição (privada) em nome de um interesse social (público). Esse mesmo dispositivo trata ainda da necessidade do livre e pleno consentimento para o casamento e da liberdade de contrai-lo sem restrição de raça, nacionalidade ou religiáo, bem como da igualdade entre os cônjuges ${ }^{23}$.

O debate sobre a família - que, por ser tanto uma estrutura pública como uma relação privada, uma vez que configura o indivíduo como integrante de um vínculo familiar e partícipe de um contexto social (DIAS, 2011) - está pautado pela tensão e pelas confluências entre a autonomia privada e a ordem pública. Até que ponto a tutela da liberdade de escolha nas relações afetivas pela ordem pública permite/restringe o exercício pleno da cidadania?

Nesse diapasão, arguindo sobre o que tornaria o Direito de Família uma questáo de ordem pública e, do outro lado da mesma moeda, até onde seriam alçados os limites das autonomias individuais, Teixeira e Rodrigues (2010) afirmam que essa apreciação deve ser feita a partir da conjunção dos conceitos de liberdade e família e da composição entre eles no plano de uma objetividade institucional, de maneira a resultar em um mínimo de restriçóes individuais e um máximo de realizaçóes pessoais. Não se pretende, com tais argumentos, defender a abstenção do Estado da regulamentação do Direito de Família, sobretudo nos casos da necessária proteção de sujeitos familiares vulneráveis, quando seu papel é promocional, mas chamar a atenção para a redefinição e a coexistência equilibrada entre as dicotomias supramencionadas ${ }^{24}$.

É imperioso demarcar o limite de intervenção do direito na organização familiar, para que as normas postas não interfiram em prejuízo do ser sujeito, destoando do processo de humanização e de repersonalização. A esfera privada das relaçóes afetivo-conjugais começa a repudiar a interferência do público, porquanto ainda que persista o interesse do Estado na preservação da família, célula da sociedade, cabe indagar sobre sua legitimidade (ou sobre seu limite) para invadir a privacidade e de intimidade das pessoas, promovendo uma verdadeira estatização do afeto (DIAS, 2011). As confluências

23 Eis os enunciados do artigo 16 da Declaração Universal dos Direitos do Homem (1948):

“1. A partir da idade núbil, o homem e a mulher têm o direito de casar e de constituir família, sem restrição alguma de raça, nacionalidade ou religiấo. Durante o casamento e na altura da sua dissolução, ambos têm direitos iguais."

"2. O casamento não pode ser celebrado sem o livre e pleno consentimento dos nubentes."

"3. A família é o elemento natural e fundamental da sociedade e tem o direito à proteção da sociedade e do Estado.”

24 Tanto o absenteísmo estatal como a interferência desmesurada são prejudiciais. Teixeira e Rodrigues (2010) salientam que, assim como no Estado Liberal, no qual o exagero da autonomia privada causou a falência do sistema, no Estado Social a excessiva ingerência na esfera de liberdade individual fez ruir postulados que privilegiavam incondicionalmente a vontade coletiva em detrimento da vontade individual. 
e dissonâncias originadas pela definição dos espaços concernentes à ordem pública e à autonomia privada, as quais estão sendo redesenhados desde a vigência do Estado Liberal, precisam levar em conta as significativas transformaçóes ocorridas em matéria de relaçóes familiares. No Estado Democrático de Direito, a plena realizaçáo do ser humano depende também da unificação dessa dicotomia em prol da concretização das reais necessidades humanas (TEIXEIRA; RODRIGUES, 2010).

Destarte, faz-se mister buscar o equilíbrio entre a autonomia privada e a ordem pública, haja vista que os modelos familiares devem ser inspirados na liberdade; as pessoas merecem ter a liberdade de formar suas famílias (esfera privada) inspiradas antes nos laços afetivos do que em modelos herméticos, e é o reconhecimento jurídico (esfera pública) dessas estruturas de convívio que possibilita o exercício da cidadania. A discussão, pois, sobre o privado e o público no âmbito do Direito de Família traz à tona as interfaces entre liberdade e cidadania, encontrando alento no pensamento de Arendt (1983), que disserta sobre a liberdade como manifestação do indivíduo no espaço público e propóe o exame da condição humana através de três atividades fundamentais que integrariam a vita activa: o labor, o trabalho e a ação.

O labor seria atividade correspondente ao processo biológico do corpo humano, assegurando a sobrevivência da espécie e relacionado, pois, à própria vida (homo laborans). $\mathrm{O}$ trabalho não estaria necessariamente contido no repetitivo ciclo vital da espécie, como ocorre no labor, mas corresponderia ao artificialismo da existência humana: é pelo trabalho que se produz um mundo artificial diferente do ambiente natural, que o homo faber cria coisas extraídas da natureza, convertendo o mundo em um espaço de objetos partilhados pelo homem. A ação seria a única atividade exercida diretamente entre homens sem a mediação das coisas ou da matéria, correspondendo à condição humana de pluralidade e estando de forma intrínseca ligada à política e à liberdade. $\mathrm{Na}$ obra de Arendt (1983), a açáo seria, portanto, uma das categorias fundamentais que possibilitaria o exercício da liberdade e a capacidade de reger o próprio destino, além de configurar expressão da singularidade individual.

O exercício da liberdade e a capacidade de reger o próprio destino consistem em direitos fundamentais das pessoas, notadamente em matéria de escolhas afetivas. As consideraçóes acerca da liberdade e da cidadania, feitas a partir de aspectos relacionados à autonomia de vontade, titularidade de direitos e obrigaçóes e participação ativa na coletividade como forma de desenvolvimento do indivíduo e da própria sociedade, possuem aplicabilidade nas questóes do Direito de Família, evidenciando-se que a principal função da família é conferir suporte emocional aos indivíduos que a integram e possibilitar o desenvolvimento de todos eles em respeito à dignidade humana.

Assim, em vista de todo o processo de humanização do direito e das relaçóes de família, da consagração do princípio da afetividade e do reconhecimento de uma pluralidade de estruturas familiares, independentemente do selo formal do matrimônio e do 
gênero dos integrantes, como justificar o repúdio jurídico às unióes poliamorosas que efetivamente tenham vínculos afetivo-familiares sem macular o princípio da dignidade e sem restringir o exercício da liberdade e da cidadania? Eis o desafio posto para reflexão.

\section{Conclusões}

Os argumentos tecidos neste artigo permitem vislumbrar algumas consonâncias e dissonâncias do processo de humanizaçáo no âmbito das relaçóes familiares: houve um significativo avanço para a democratização da família, com a ampliação e a consequente tutela jurídica de estruturas familiares diversas das formadas pelo matrimônio legal, como aquelas sustentadas pelos vínculos de parentalidade (monoparental, parental e anaparental) e as decorrentes das unióes estáveis entre hetero e homossexuais, incluindo-se nesse rol as unióes estáveis paralelas aos casamentos, desde que comprovada a separação de fato entre os cônjuges.

O problema ainda reside no paralelismo afetivo das unióes poliamorosas consentidas, ou seja, no reconhecimento jurídico do poliamor. A ausência de tutela jurídica nesses casos, em princípio, destoa desse processo de humanização e de repersonalização do direito, desviando a aplicabilidade plena dos princípios da dignidade e da afetividade e o exercício da liberdade e da cidadania por essas pessoas que, consensualmente, resolveram manter relacionamentos não convencionais, não monogâmicos.

A família tem como função a realização e o desenvolvimento de todos os seus membros, na condição de sujeitos de direito dotados de dignidade, devendo o princípio da dignidade humana ser compreendido como princípio respeitante a todos e a cada a um dos integrantes do grupo familiar. Por ser uma construção cultural, base do Estado e célula da organização social, a família merece ser interpretada independentemente do tipo de arranjo familiar em que se revela, em especial porque a Constituição da República Federativa do Brasil é inclusiva.

A afetividade, aspecto representativo da noção hodierna de família, haja vista que é o envolvimento afetivo que possibilita o pleno desenvolvimento do ser humano, de sua individualidade e de sua privacidade, adentrou no elenco principiológico do Direito de Família como elemento nuclear que reflete a constitucionalização de modelos de famílias eudemonistas e igualitários. Esse respaldo jurídico do afeto sinaliza a repersonalizaçáo do direito, no sentido da clara opção de privilegiar o ser em detrimento do ter (a despatrimonialização e a personalização de institutos jurídicos através da inserção da pessoa humana no centro protetor do direito).

A dignidade humana e a afetividade, dentre outros princípios aplicáveis ao Direito de Família (solidariedade, convivência familiar, igualdade), estão em conexão com a liberdade de escolha, a autonomia privada e o modo de pertencimento e de participaçáo 
das pessoas na coletividade, o que se traduz em cidadania, em titularidade (e exercício) de direitos e deveres. Em outras palavras, como a família é, ao mesmo tempo, uma relação privada e uma estrutura pública, porque seus integrantes mantêm vínculos afetivo-familiares e são partícipes de um contexto social, não há como pensar as relaçóes familiares sem a reflexão sobre as confluências e dissonâncias entre a autonomia privada e a ordem pública.

Os modelos de família devem ser inspirados na liberdade, e o seu reconhecimento depende da harmonia entre autonomia privada e ordem pública; dessa maneira, cada ser humano poderá exercer sua cidadania com plenitude.

\section{Referências}

ARENDT, Hannah. A condição humana. Rio de Janeiro: Forense Universitária, 1983.

BAUMAN, Zygmunt. Modernidade líquida. Rio de Janeiro: Zahar, 2001.

Amor líquido: sobre a fragilidade dos laços humanos. Rio de Janeiro: Zahar, 2004.

BIROLI, Flávia. Família: novos conceitos. São Paulo: Fundação Perseu Abramos/Partido dos Trabalhadores, 2014. Disponível em: <http://www.fpabramo.org.br>. Acesso em: 18 fev. 2015.

BELIEN, Paul. First Trio 'Married' in the Netherlands. The Brussels Journal: the voice of conservatism in Europe. Disponível em <http://www.brusselsjournal.com>. Acesso em: 14 maio 2015.

BODIN DE MORAES, Maria Celina. A nova família, de novo - Estruturas e função das famílias contemporâneas. In: Revista Pensar, v. 18, n.2. Fortaleza: Fundação Edson Queiroz, Universidade de Fortaleza. Disponível em <http://www.unifor.br > . Acesso em: 26 fev. 2015.

BRASIL. Código Civil. São Paulo: Saraiva, 2014.

. Constituição (1988). Constituição da República Federativa do Brasil. São Paulo: Saraiva, 2014.

. Lei 9.278/96. Regula o $\$ 3^{\circ}$ do art. 226 da Constituição Federal. Diário Oficial da União. Brasília, DF, 13 maio 1996.

CARVALHO, Dimitre Braga Soares de. Direito de família e direitos humanos: pluralidade familiar e dignidade humana como centro das relaçóes familiares. São Paulo: EDIJUR, 2012.

DALANEZE, Sérgio. Contribuição do pluralismo no debate das ideias jurídicas. In: WOLKMER, Antonio Carlos; VERAS NETO, Francisco; LIXA, Ivone (orgs.). Pluralismo jurídico: os novos caminhos da contemporaneidade. São Paulo: Saraiva, 2010. 
DIAS, Maria Berenice. Manual de direito das famílias. São Paulo: RT, 2011.

DECLARAÇÃO UNIVERSAL DOS DIREITOS HUMANOS (1948). Declaração Universal dos Direitos Humanos. Disponível em: <http://www.dhnet.org.br>. Acesso em: 13 fev. 2015.

ENGELS, Friedrich. A origem da família, da propriedade privada e do Estado. Coleção Grandes Obras do Pensamento Universal - 2. São Paulo: Escala, s/d. Coleção Grandes Obras do Pensamento Universal - 2.

FREIRE, Sandra Elisa de Assis. Poliamor, uma forma não exclusiva de amar: correlatos valorativos e afetivos. Tese (Doutorado em Psicologia Social). Universidade Federal da Paraíba. João Pessoa, 2013.

G1, BAURU E MARÍLIA. União estável entre três pessoas é oficializada em cartório de Tupã, SP: um homem e duas mulheres fizeram escritura pública de união poliafetiva. Documento dá direitos de família, especialmente em casos de separação. Disponível em: <http://www.g1.globo.com>. Acesso em 14 maio 2015.

GOMES, Orlando. Raízes históricas e sociológicas do Código Civil brasileiro. São Paulo: Martins Fontes, 2003.

LIMA, Alceu Amoroso. A família no mundo moderno. Rio de Janeiro: Agir Editora, 1960.

OLIVEIRA, Catarina Almeida de. Refletindo o afeto nas relaçôes de família. Pode o direito impor amor? In: ALBUQUERQUE, Fabíola Santos; EHRHARDT JR., Marcos; OLIVEIRA, Catarina Almeida de (coords.). Famílias do direito contemporâneo: estudos em homenagem a Paulo Luiz Netto Lôbo. Salvador: Jus Podivm, 2010.

OLIVEIRA, José Sebastiāo de. Fundamentos constitucionais do Direito de Família. São Paulo: RT, 2002.

ÖRÜCÜ, Esin. Family law. In: BUSSANI, Mauro; WERRO, Franz (orgs.). European private law: a handbook. Berna: Stämpfli Publishers Ltd., 2009.

ROUDINESCO, Elisabeth. A família em desordem. Rio de Janeiro: Zahar, 2003.

ROUSSEAU, Jean-Jacques. A origem da desigualdade entre os homens. São Paulo: Escala, s/d. Coleção Grandes Obras do Pensamento Universal - 7.

SANTO AGOSTINHO. A cidade de Deus. São Paulo: Biblioteca de Cultura Cristá, Ed. das Américas S/A, 1964.

SUPREMO TRIBUNAL FEDERAL. Disponível em <http://stf.jus.br. Acesso 08 fev. 2015.

TEIXEIRA, Ana Carolina Brochado; RODRIGUES, Renata de Lima. O direito das familias entre a norma e a realidade. São Paulo: Atlas, 2010. 